\title{
Pengaruh beban kerja terhadap kinerja karyawan pada food and beverage service department di hotel artotel sanur bali
}

\author{
Megananda Pranadika ${ }^{1)}$, Ni Made Ariani' ${ }^{2)}$, Agus Muriawan Putra ${ }^{3)}$ \\ Program Studi Diploma IV Pariwisata, Fakultas Pariwisata, Universitas Udayana \\ J1. Dr. Goris No. 7, Denpasar, Kode Pos : 80232, Telp/Fax : 0361-223798 \\ Email : megapranadika2@gmail.com
}

\begin{abstract}
Abstrak
Penelitian ini didasari dengan begitu besarnya peranan sumber daya manusia untuk pencapaian tujuan organisasi, maka kehadiran sumber daya manusia yang memiliki kecakapan dan ketrampilan sangat dibutuhkan. Pelayanan yang harus diberikan kepada tamu dan kendala yang dihadapi tentunya diperlukan organisasi yang solid mulai dari kary awan yang berhadapan langsung dengan tamu sampaidenganpimpinan yang mengambilkeputus an dan kebijakan dalammemahami kebutuhan karyawan sehing gadapatmemberkan kinerja yang baik bagi karyawan. Dengan kondisi tersebut tentunya organisasi membutuhkan keberadaan sumber daya manusia yang baik, handal dan professional agar mampu memberi kinerja yang diinginkan organisasi. Tujuan penelitian ini untuk mengetahui pengaruh beban kerja terhadap kinerjakaryawanpada food and beverage service department di Hotel Artotel Sanur, Bali. Populasi dari penelitian iniadalah karyawan tetap dan kontrak food and beverage service department di Hotel Artotel Sanur, Bali sejumlah 40 orang. Pengumpulan data primer dilakukan dengan penyebaran kuesioner kepada seluruh karyawan food and beverage service department di Hotel Artotel Sanur, Bali. Teknik pengambilan sampel menggunakan metode sensus sehingga sampel adalah seluruh populasi yang berjumlah 40 orang. Pada penelitian ini terdapatsatu variabelindependen yang dianalis is yaitu beban kerja, sementara variabel dependen adalahkinerja.Datayang terkumpul selanjutnya dianalis is menggunakan teknik analis is regresi linier sederhana. Berdasarkan hasil analisis hipotes is pertama tentang pengaruh beban kerja terhadap kinerja karyawan diperolehnilait ${ }_{\text {hing }}$ sebesar 4,325 memiliki nilai lebih besar dari tabel sebesar 2,024 deng an nilai signifikan $0,000<0,05$ artiny a terdapat pengaruh yang signifikan terhadap kinerja kayawan food and beverage service department di HotelArtotel Sanur, Bali. Jenis dan sumber data dalampenelitian ini adalah kuantitatif dan kualitatif. Hasil penelitian ini selaras dengan temuan beberapa peneliti terdahulu yang membuktikan bahwa beban kejabepengaruhpositif dan signifikan terhadap kinerja karyawan.
\end{abstract}

Kata kunci: Beban kerja, Kinerja

\begin{abstract}
Abs tract
This research is based on the magnitude of the role of human resources for the achievement of organizational goals, The services that must be given to guests and the obstacles they face are certainly needed by a solid organization, starting fromemployees who deal directly with guests to leaders who makedecisions andpolicies in understanding the needs of employees so that they can provide good performance for employees. With these conditions, of course, the organization requires the exis tence of good, reliable and profes sional human resources to be able to provide the desired performance of the organization. The purposeofthis study was to determine the effect of workload on employee performance at the food and beverageservicedepartment at Hotel Artotel Sanur, Bali. The Population of this study are permanent employees and food and beverag e service department contracts in the Artotel Hotel Sanur, Bali. The sampling technique usescensus methodso that the sample is the entire population of 40 people. In this study there is one independent variableanalyzed, namely workload, while the dependent variable is performance. The collected data is thenanalizedusing simple linier regression analysis technique. Based on the results of the first hypothesis analys is about the effectof workload on employee performance obtained tcount of $4.325 \mathrm{has}$ a v alue greater than ttable of 2.024 with a significant value of $0.000<0.05$ means that there is significant effect on the performance of rich food and beverage service department at Hotel Artotel Sanur, Bali. The types and sources of data in this study are quantitative and qualitative. The result of this study are in line with the findings of severalprevious researchers who proved that workload has a positive and significant effect on employee performance.
\end{abstract}

Keywords: Workload, The Performance. 


\section{PENDAHULUAN}

Pariwisata merupakan suatu kegiatan wisata atau berkunjung ke suatu daerah atau negara lain dengan tujuan untuk berlibur ataupun rekreasi dan tidak menetap. Bali adalah salah satu pulau di Indonesia yang memiliki potensi pariw isata yang besar dan terkenal di mancanegara karena Bali kaya akan alam, budaya, seni, adat istiadat, dan masyarakat yang ramah dengan wisatawan. Kunjungan wisataw an nusantara maupun mancanegara ke Bali meningkat setiap tahunnya. Berikut data dan informasi terkait jumlah kunjungan wisatawan mancanegara dan domestik ke Bali dari Tahun 2012-2017 pada Tabel 1.

Tabel 1. Data Kunjungan Wisatawan Mancanegara dan Domestik ke Bali Tahun 2012-2017 Jumlah (Orang)

$\begin{array}{ccccc}\text { Tahun } & \begin{array}{c}\text { Wisatawan } \\ \text { Mancanegara }\end{array} & \text { Wisatawan Domestik } & \text { Total } & \begin{array}{c}\text { Pertumbuhan } \\ (\%)\end{array} \\ 2013 & 3.278 .598 & 6.976 .536 & 10.255 .134 & - \\ 2014 & 3.766 .638 & 6.392 .460 & 10.159 .098 & -0,95 \\ 2015 & 4.001 .835 & 2.147 .100 & 11.148 .935 & 9,7 \\ 2016 & 4.927 .937 & 8.643 .680 & 13.571 .617 & 21,7 \\ 2017 & 5.697 .739 & 8.735 .633 & 14.433 .372 & 6,3 \\ \text { Total } & 21.672 .747 & 32.895 .409 & 59.568 .156 & 36,75 \\ \text { Rata-Rata } & 4.334 .549 & 6.579 .082 & 11.913 .631 & 7,35\end{array}$

Sumber: Dinas Pariwis ata Bali, 2019.

Berdasarkan Tabel 1 dapat diambil kesimpulan bahw a sebagian besar kunjungan wisataw an mancanegara dan domestik mengalami kenaikan. Pada tahun 2017 merupakan kunjungan wisatawan terbanyak dengan total 59.568.156 wisatwan diantaranya wisataw an mancanegara sebanyak orang 5.697.739 dan wisatawan domestik mencapai 8.735.633 orang dengan pertumbuhan mencapai6,3\% dari tahun sebelumnya. Pertumbuhan kunjungan wisataw an mancanegara dan domestik memiliki rata-rata pertumbuhan 7,35\% setiap tahunnya. Kunjungan wisataw an manc anegara dan wisataw an domestik mengalami kenaikan yang semakin membuat Bali menjadi tujuan destinasi wisata terfavorit di Indonesia. Menurut Keputusan Menteri Parpostel no Km 94/HK103/MPPT (1987) menyatakan bahwa Hotel adalah: "Salah satu jenis akomodasi yang mempergunakan sebagian atau keseluruhan bagian untuk jasa pelayanan penginapan, penyedia makanan dan minuman serta jasa lainnya". Perkembangan hotel di Bali sangatlah pesat bisa terlihat di setiap Kabupaten di Bali, terutama di daerah Nusa Dua, Jimbaran, Kuta dan Sanur yaitu di daerah tersebut banyak terlihat pembangunan hotel. Berikut adalah data akomodasi yang tersedia disetiap kabupaten di Bali pada Tabel 2.

Tabel 2. Data Akomodasi Berbintang dan Non Bintang di Provinsi Bali Tahun 2012-2016

\begin{tabular}{cccccccccc} 
No & Kabupaten & \multicolumn{2}{c}{ Pondok Wisata } & \multicolumn{2}{c}{ Hotel Melati } & \multicolumn{2}{c}{ Hotel Bintang } & \multicolumn{2}{c}{ Total Akomodasi } \\
& & $\begin{array}{c}\text { Pondok } \\
\text { wisata }\end{array}$ & Kamar & $\begin{array}{c}\text { Hotel } \\
\text { Melati }\end{array}$ & Kamar & Hotel & Kamar & Jumlah & Total \\
Bintang & & & Akomodasi & kamar \\
1 & Denpasar & 2 & 364 & 211 & 4926 & 26 & 3591 & 309 & 8881 \\
2 & Badung & 16 & 2527 & 406 & 19804 & 157 & 26368 & 1279 & 48629 \\
3 & Gianyar & 1077 & 4586 & 198 & 2813 & 14 & 621 & 1289 & 8020 \\
4 & Tabanan & 25 & 489 & 72 & 1158 & 4 & 365 & 201 & 2012
\end{tabular}




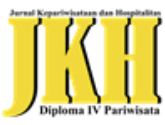

$5 \quad$ Klungkung

6 Bangli

7 Karangasem

8 Jembrana

9 Buleleng

12

$$
33
$$

181

1011

54

796

1152

6

125

187

3092

39

63

583

1180

187

JURNAL KEPARIWISATAAN DAN HOSPITALITAS
Vol. 4, No. 1, April 2020.

20

0

0

18

1048

179

4604

$\begin{array}{llll}0 & 0 & 84 & 622\end{array}$

$\begin{array}{llll}11 & 501 & 514 & 4557\end{array}$

Sumber: Dinas Pariwis ata Provinsi Bali, 2019.

Berdasarkan Tabel 2 dapat dilihat bahwa data akomodasi berbintang dan non bintang di provinsi Bali terbanyak terdapat di Kabupaten Badung. Kabupaten Badung merupakan daerah yang menjadi satu-satunya gerbang kedatangan wisatawan baik mancanegara maupun nusantara melalui transportasi udara, hal ini tidak mengherankan jika Kabupaten Badung memiliki jumlah akomodasi yang banyak dengan total sejauh ini 48629 kamar. Pada urutan kedua dapat dilihat bahwa Kota Denpasar menjadi daerah yang memiliki akomodasi terbanyak setelah Kabupaten Badung dan disusul oleh kabupaten lainnya. Banyak persaingan hotel yang terjadi di Bali, untuk memenangkan persaingan, hotel-hotel di Bali ada yang meningkatkan pelayanannya kepada pengunjung, itu bagus. Banyak hotel yang menurunkan harga untuk membuat hati wisatawan nusantara maupun mancanegara. Ini yang membuat menarik minat iklim bisnis menjadi tidak sehat. Untuk memenuhi tuntutan kinerja perusahaan yang tinggi dan meningkatkan target pendapatan hotel, banyak hotelhotel yang bersaing dengan cara merusak bisnis dengan menurunkan harga yang begitu murah, sehingga hal ini merusak pasaran hotel di Bali. Dengan begitu hal ini juga otomatis berdampak pada karyaw an dimana perusahaan juga akan menuntut karyaw an untuk meningkatkan kualitas pelayanan yang tinggi dengan budget yang minim demi mengurangi biaya produksi perusahaan.

Persaingan kerja yang ketat akan menyebabkan para karyawan merasa tertekan, mudah tersinggung dan akhirnya menimbulkan beban kerja, menurut Kurnia, Adil (2010) Beban kerja merupakan: "suatu proses Analisa terhadap waktu yang digunakan oleh seseorang atau sekelompok orang dalam menyelesaikan tugas-tugas suatu pekerjaan (jabatan) atau kelompok jabatan (unit kerja) yang dilaksanakan dalam keadaan/kondisi normal". Pengertian lain menyatakan bahwa beban kerja merupakan salah satu aspek yang harus diperhatikan oleh setiap perusahaan, karena beban kerja menybabkan menurunnya kinerja karyawan. Jika seorang karyaw an mengalami beban kerja yang terlalu besar, maka akan mengganggu kemampuan seseorang tersebut untuk menghadapi lingkungan dan pekerjaannya".

Salah satu hotel yang terdapat di Sanur adalah Artotel Sanur Bali, hotel berbintang 4 ini memiliki keunikan dari segi arsitektur, interior dan desain bangunan hingga manajemen yang ada di dalamnya. Salah satu kekhasan Artotel Sanur Bali adalah interior bangunan yang berbentuk layanglayang dan desain dengan tema berbeda disetiap kamar hotel. Layang-layang merupakan ikon dari daerah Sanur, dan hal ini diimplementasikan oleh Artotel Indonesia dalam penggabungan interior desain Artotel Sanur Bali untuk menarik wisatawan yang akan menginap. Kamar yang tersedia di Artotel Sanur Bali tidaklah banyak, hanya ada 89 kamar hal ini dikarenakan Artotel Sanur Bali merupakan hotel yang memiliki nilai seni kontemporer murni yang nantinya akan disajikan untuk para penikmat seni dalam bentuk akomodasi hotel.

Di tahun 2018 menurut Ibu Maya selaku Manager Human Resources Department menyebutkan:

"turnover karyawan yang tinggi setiap tahunnya, mempengaruhi beban kerja karyawan lainnya, hal ini dikarenakan berkurangnya jumlah tenaga karyaw an di department food and beverage service. Alasan tingginya turnover di department food and beverage service disebabkan bebarapa hal diantaranya terdapat banyak masalah antara karyaw an dan manajemen sering terjadinya overtime kerja lebih dari 2 jam, tekanan atau desakan waktu dalam bekerja. Alasan tersebut membuat karyaw an merasa terbebani dan tidak nyaman sehingga banyak karyawan yang mengajukan resign". 
Hotel Artotel Sanur Bali memiliki 10 departemen, yaitu Human Resources Department, Front Office Department, Sales and Marketing Department, IT Department, Housekeeping Department, Engineering Department, Security Department, SPA dan Food and Beverage Service Department, Food and Beverage Product Department, tingkat turnover karyaw an yang paling tinggi adalah di Food and Beverage Service Department yang dapat dilihat pada Tabel 3.

Tabel3. Data Turnover Karyawan pada Food and Beverage Service Department di Hotel Artotel SanurBali Tahun 2016-2018

\begin{tabular}{|c|c|c|c|c|c|}
\hline Tahun & $\begin{array}{c}\text { Jumlah } \\
\text { Karyawan awal } \\
\text { tahun (Orang) }\end{array}$ & $\begin{array}{c}\text { Jumlah } \\
\text { Karyawan yang } \\
\text { Keluar (Orang) }\end{array}$ & $\begin{array}{c}\text { Jumlah } \\
\text { Karyawan masuk } \\
\text { (Orang) }\end{array}$ & $\begin{array}{c}\text { Jumlah } \\
\text { Karyawan Akhir } \\
\text { Tahun (Orang) }\end{array}$ & $\begin{array}{c}\text { Turnover Rate } \\
(\%)\end{array}$ \\
\hline 2016 & 60 & 6 & 2 & 56 & 6 \\
\hline 2017 & 56 & 9 & 3 & 50 & 9 \\
\hline 2018 & 50 & 14 & 4 & 40 & 18 \\
\hline
\end{tabular}

Sumber: Human Resources Department Artotel Sanur Bali, 2018.

Berdasarkan Tabel 3 dapat dilihat persentase tingkat turnover karyawan pada Food and Beverage Service Department di Hotel Artotel Sanur Bali mengalami peningkatan dari tahun 2016 sampai dengan tahun 2018. Pada tahun 2016 karyawan keluar sebanyak 6 orang, sedangkan jumlah karyawan masuk sebanyak 2 orang. Tingkat persentase turnover sebanyak 6\%, Pada tahun 2017 karyaw an keluar sebanyak 9 orang, sedangkan jumlah karyawan masuk sebanyak 3 orang. Tingkat persentase turnover meningkat sebanyak 9\% dan pada tahun 2018 karyawan keluar sebanyak 14 orang, sedangkan jumlah karyawan masuk sebanyak 4 orang. Tingkat persentase turnover mengalami pengingkatan yang paling tinggi yaitu sebanyak $18 \%$.

Sebagaian karyawan yang keluar adalah karyaw an tetap yang sudah memiliki masa kerja selama kurang lebih diatas 6 bulan. Berdasarkan hasil waw ancara dengan pihak HRD diperoleh beberapa alasan karyawan keluar dari hotel, yaitu beban kerja yang berlebihan, hubungan pekerja dengan pekerja lainnya kurang harmonis, lamanya waktu kerja atau overtime. Selain itu adanya keluh kesah dari karyawan mengenai hubungan karyawan dengan pemimpin yang kurang mendukung dalam melaksanakan pekerjaan. Berdasarkan penjelasan diatas terkait jumlah karyawan yang terus mengalami turnover.

Tabel 4. Data Kary awan Resign pada Food and Beverage Service Department DiHotel Artotel Sanur Bali Tahun 2016-2018

Tahun

2016

2017

2018

Total
Total Karyawan Resign

4

6

10

20
Persentase Karyawan Resign

20

30

48

100

Sumber: Human Resources Department Employee Resign (Data Diolah, 2018)

Tabel 4 di atas dapat di analisis bahwa pada tahun 2016 sampai tahun 2018 persentase karyawan yang resign setiap tahunnya terus bertambah, hal ini disebabkan oleh berbagai macam masalah di department Food and Beverage Service dan menyebabkan banyak karyawan yang mengajukan resign. Alasan karyaw an resign pada tiap tahunnya antara lain beban kerja yang sulit dan berlebihan, tekanan atau desakan waktu, alat bantu kerja dan sarana kerja kurang memadai, kondisi pekerjaan atau medan kerja yang kurang baik, hubungan antar karyaw an kurang harmonis dan lamanya waktu kerja atau overtime. Rata-rata umur dari karyaw an yang resign diantara umur 
23-25 tahun, faktor tersebut juga yang menjadi alasan karyawan untuk mencari pengalaman kerja di tempat lainnya. Sebagaian karyaw an yang keluar adalah karyawan tetap yang sudah memiliki masa kerja selama rata-rata kurang lebih diatas 6 bulan.

Persentase turnover yang melebihi standar yaitu diatas $10 \%$ tergolong sangat tinggi, sehingga hal ini menjadi perhatian yang serius bagi pihak manajemen terutama di Department Food and Beverage Service untuk mencari tahu penyebabnya dan untuk dapat mengendalikan supaya angka turnover tidak terlalu tinggi, karena jika setiap tahunnya terjadi turnover yang terlalu tinggi ini akan berdampak juga pada perusahaan dengan mengeluarkan biaya yang tidak sedikit untuk melakukan perekrutan karyaw an baru, training, proses adaptasi, dan juga karyaw an yang bagus dapat terpengaruh karena adanya beberapa karyawan yang mengalami beban kerja yang dapat menimbulkan konflik di dalam organisasi.

Tabel 5. Data Kary awan Food and Beverage Service Department di Hotel Artotel Sanur BaliTahun 2016-2018

$\begin{array}{cccc}\text { Tahun } & \text { Jumlah Karyawan ROCA } & \text { Jumlah Karyawan BART (Bar } & \text { Total Karyawan } \\ & \text { (Resturant Of Comtemporary Art) } & \text { At The Rooftop) } & \end{array}$

$\begin{array}{llll}2016 & 41 & 15 & 56 \\ 2017 & 35 & 15 & 50 \\ 2018 & 25 & 15 & 40\end{array}$

Sumber: Food and Beverage Service Department, 2018.

Berdasarkan Tabel 5 diatas dapat dilihat bahw a jumlah karyaw an food and beverage service department yang ada di Hotel Artotel Sanur Bali pada tahun 2016 sebanyak 56 karyaw an, yang terdiri dari 41 karyawan ROCA dan 15 karyawan BART. Pada tahun 2017 mengalami penurunan menjadi 50 karyawan, yang terdiri dari 35 karyawan ROCA dan 15 karyawan BART. Pada tahun 2018 mengalami penurunan menjadi 40 karyawan, yang terdiri dari 25 karyawan ROCA dan 15 karyaw an BART.

Tabel 6. Jumlah Kunjungan Wisatawan Mancanegara dan Domestik yang Menikmati Makanan di ROCA Restoran Artotel Sanur Bali Tahun 2016-2018

\begin{tabular}{ccccc}
\multicolumn{4}{c}{ Jumlah (Orang) } \\
Tahun & $\begin{array}{c}\text { Wisatawan } \\
\text { Mancanegara }\end{array}$ & $\begin{array}{c}\text { Wisatawan } \\
\text { Domestik }\end{array}$ & Total & $\begin{array}{c}\text { Pertumbuhan } \\
\text { 2016) }\end{array}$ \\
2017 & 59.597 & 32.074 & 91.671 & - \\
2018 & 91.606 & 48.156 & 139.762 & 52,46 \\
Total & 93.006 & 49.510 & 142.516 & 1,97 \\
\hline Rata-rata & 244.209 & 129.740 & 373.949 & 54,43 \\
& \multicolumn{1}{l}{} & 18,14
\end{tabular}

Sumber: Human Resources Department Artotel Sanur Bali, 2019

Pada Tabel 6 dapat dilihat jumlah wisatawan yang berkunjung di Artotel Sanur Bali mengalami pertumbuhan rata-rata sebesar 18,14 persen. Pertumbuhan tertinggi terjadi pada tahun 2017 sebesar 52,46 persen. Hal ini dikarenakan Artotel Sanur Bali memiliki review yang cukup bagus atau unik serta menarik minat wisatawan mancanegara maupun domestik. Peningkatan tingkat kunjungan wisatawan di restoran yang terjadi setiap tahun ini disebabkan adanya beberapa review bagus yang memberi dampak positif bagi Artotel Sanur Bali. 
Tabel 7. Jumlah Kunjungan Wis atawan Mancanegara dan Domestik yang Menikmati Minuman diBARTBar Artotel Sanur Bali Tahun 2016-2018

Jumlah (Orang)

Tahun Wisatawan Mancanegara Wisatawan Domestik Total Pertumbuhan

\begin{tabular}{ccccc} 
& & & & $(\%)$ \\
2016 & 33.780 & 15.980 & 49.760 & - \\
2017 & 36.494 & 25.547 & 62.041 & 24,68 \\
2018 & 38.310 & 26.818 & 65.128 & 4,97 \\
Total & 109.956 & 76.973 & 186.929 & 29,65 \\
\hline \multicolumn{2}{c}{} & & 9,88
\end{tabular}

Sumber: Human Resources Department Artotel Sanur Bali, 2019

Pada Tabel 7 dapat dilihat jumlah wisatawan yang berkunjung di Artotel Sanur Bali mengalami pertumbuhan rata-rata sebesar 9,88 persen. Pertumbuhan tertinggi terjadi pada tahun 2017 sebesar 24,68 persen. Hal ini dikarenakan Artotel Sanur Bali memiliki review yang cukup bagus atau unik serta menarik minat wisatawan mancanegara maupun domestik. Peningkatan tingkat kunjungan wisatawan di bar yang terjadi setiap tahun ini disebabkan adanya beberapa review bagus yang memberi dampak positif bagi Artotel Sanur Bali.

Dampak yang positif tersebut membuat berbagai macam faktor yang dapat meingkatkan peforma dari kinerja karyaw an incharge di Artotel Sanur Bali. Berikut adalah untuk mengetahui beban kerja yang diterima oleh karyaw an dilakukan pengecekan jumlah karyawan incharge di setiap tempat yang ada di Food and Beverage Service Department seperti yang terlihat berikut pada Tabel 8 .

Tabel 8. Daily StaffIncharge Pada Food And Beverage Service Department di Artotel Sanur BaliTahun2016 $-2018$

\begin{tabular}{|c|c|c|c|c|c|c|c|c|c|}
\hline \multicolumn{9}{|c|}{ Jumlah Karyawan Incharge dan Shift Karyawan } & \multirow{4}{*}{$\begin{array}{c}\text { Total } \\
\text { Karyawa } \\
\mathrm{n} \\
\text { Incharge }\end{array}$} \\
\hline \multirow{3}{*}{$\begin{array}{c}\text { Tahu } \\
\mathrm{n}\end{array}$} & \multicolumn{8}{|c|}{ Shift Pagi (06.00-15.00) } & \\
\hline & \multicolumn{2}{|c|}{$\begin{array}{c}\text { ROCA } \\
\text { (Restaurant Of } \\
\text { Contemporary Art) }\end{array}$} & \multicolumn{2}{|c|}{$\begin{array}{l}\text { Total Karyawan } \\
\text { Incharge } \\
\text { Per seat }\end{array}$} & \multicolumn{2}{|c|}{$\begin{array}{c}\text { BART } \\
\text { (Bart At The } \\
\text { Rooftop) }\end{array}$} & \multicolumn{2}{|c|}{$\begin{array}{c}\text { Total Karyawan } \\
\text { Incharge } \\
\text { Per seat }\end{array}$} & \\
\hline & $\begin{array}{c}\text { Karyawa } \\
\mathrm{n} \\
\text { Incharge }\end{array}$ & $\begin{array}{c}\text { Kapasita } \\
\text { s Seat }\end{array}$ & $\begin{array}{l}\text { Karyawa } \\
\mathrm{n} \\
\text { Incharge }\end{array}$ & $\begin{array}{l}\text { Jumla } \\
\text { h seat }\end{array}$ & $\begin{array}{l}\text { Karyawa } \\
\mathrm{n} \\
\text { Incharge }\end{array}$ & $\begin{array}{l}\text { Kapasita } \\
\text { s Seat }\end{array}$ & $\begin{array}{l}\text { Karyawa } \\
\mathrm{n} \\
\text { Incharge }\end{array}$ & $\begin{array}{l}\text { Jumla } \\
\text { h seat }\end{array}$ & \\
\hline 2016 & 17 & 180 & 1 & 10 & 4 & 80 & 1 & 20 & 21 \\
\hline 2017 & 14 & 180 & 1 & 13 & 4 & 80 & 1 & 20 & 18 \\
\hline 2018 & 9 & 180 & 1 & 20 & 4 & 80 & 1 & 20 & 13 \\
\hline \multirow{3}{*}{$\begin{array}{c}\text { Tahu } \\
\mathrm{n}\end{array}$} & \multicolumn{8}{|c|}{ Shift Sore $(15.00-00.00)$} & \\
\hline & \multicolumn{2}{|c|}{$\begin{array}{c}\text { ROCA } \\
\text { (Restaurant Of } \\
\text { Contemporary Art) }\end{array}$} & \multicolumn{2}{|c|}{$\begin{array}{l}\text { Total Karyawan } \\
\text { Incharge } \\
\text { Per seat }\end{array}$} & \multicolumn{2}{|c|}{$\begin{array}{c}\text { BART } \\
\text { (Bart At The } \\
\text { Rooftop })\end{array}$} & \multicolumn{2}{|c|}{$\begin{array}{l}\text { Total Karyawan } \\
\text { Incharge } \\
\text { Per seat }\end{array}$} & \multirow{2}{*}{$\begin{array}{c}\text { Total } \\
\text { Karyawa } \\
\mathrm{n} \\
\text { Incharge }\end{array}$} \\
\hline & $\begin{array}{l}\text { Karyawa } \\
\mathrm{n} \\
\text { Incharge }\end{array}$ & $\begin{array}{c}\text { Kapasita } \\
\text { s Seat }\end{array}$ & $\begin{array}{l}\text { Karyawa } \\
\mathrm{n} \\
\text { Incharge }\end{array}$ & $\begin{array}{l}\text { Jumla } \\
\text { h seat }\end{array}$ & $\begin{array}{l}\text { Karyawa } \\
\mathrm{n} \\
\text { Incharge }\end{array}$ & $\begin{array}{c}\text { Kapasita } \\
\text { s Seat }\end{array}$ & $\begin{array}{l}\text { Karyawa } \\
\mathrm{n} \\
\text { Incharge }\end{array}$ & $\begin{array}{l}\text { Jumla } \\
\text { h seat }\end{array}$ & \\
\hline 2016 & 16 & 180 & 1 & 11 & 3 & 80 & 1 & 26 & 19 \\
\hline 2017 & 13 & 180 & 1 & 14 & 3 & 80 & 1 & 26 & 16 \\
\hline 2018 & 8 & 180 & 1 & 22 & 3 & 80 & 1 & 26 & 11 \\
\hline
\end{tabular}

Sumber: Food and Beverage Service Department, 2018.

ROCA (Restaurant Of Contemporary Art) berjenis restaurant casual dining, restoran casual dining menyediakan menu-menu dengan harga standard dan suasana bersantap casual (santai). Casual dining restaurant biasanya melayani dengan cara table service, kecuali buffet. Restoran ini juga biasanya memiliki bar terpisah yang menyediakan menu-menu bir dan beberapa menu wine. 
Menu-menu yang disediakan ROCA (Restaurant Of Contemporary Art) antara lain menu breakfast yaitu two egg any style (scramble, sunny side up, omelets), egg benedict, roca berry bowl, croissant Nutella. Menu appetizer \& soup, menu burger \& sandwich, menu pasta, menu asian main, menu western mains, menu pizza, menu to share dan menu sweet. Menu-menu yang di sediakan di BART (Bar At The Rooftop) antara lain menu signature cocktail, classic twist, unforgotten, the martini's, wine cocktail, house pouring, spirits vodka, rum, gin, tequila, brand \& cognac, whiskey, beer, mocktail, fresh juice, milk shake, soft drinks and minerals, coffe \& tea. bahwa:

Menurut Rini dan Erik selaku karyaw an food and beverage service department menyatakan

"Kunjungan tamu yang menikmati makanan pada waktu breakfast, lunch dan dinner sangat ramai bahkan berlebih, hal ini di karenakan saat breakfast, para tamu yang menginap selalu menikmati sarapan di ROCA (Restaurant Of Contemporary Art) maupun tamu dari luar hotel yang datang hanya sekedar untuk menikmati sarapan. Terdapat berbagai macam menu dan paket makanan dengan harga hemat setiap harinya yang ditawarkan oleh ROCA untuk lunch dan dinner.

ROCA juga ramai karena adanya event makanan maupun cooking class dan live cooking yang diadakan untuk tamu hotel maupun luar hotel. Selain itu, harga juga menjadi alasan ramainya ROCA, salah satunya event Rasa Lokal yang menyajikan paket makanan All you can eat khas Indonesia setiap hari senin, event Friday Fever menawarkan banyak menu hidangan steak sapi hingga steak salmon dengan harga dibaw ah Rp.100.000 setiap hari jumat.

Setiap hari sabtu ROCA memiliki event Cocktail Carnival yang menjual makan untuk dinner dengan taw aran free flow cocktail. Hal inilah yang membuat karyaw an kewalahan dan menjadibeban kerja yang berlebihan saat melayani tamu. Kunjungan tamu yang menikmati minuman di BART (Bar At The Rooftop) bisa dikatakan sangat ramai, hal ini dikarenakan banyak tamu yang memesan minuman sembari bersantai, melakukan spa atau sedang berenang setiap harinya, karena lokasi BART dekat dengan pool dan spa. Terdapat banyak event yang dilakukan di BART antara lain splash Sunday, birthday party, fun gathering dan catatan anak disko. Pada saat malam hari juga banyak tamu yang party di BART tersebut hingga waktu yang di tentukan, hal inilah yang menyebabkan karyaw an kewalahan saat melayani tamu dan menyebabkan beban kerja yang cukup berat".

Berdasarkan hasil wawanc ara oleh Rini dan Erik selaku karyaw an food and beverage service department menyatakan bahwa kunjungan tamu yang menikmati makanan dan minuman di ROCA (Restaurant Of Contemporary Art) dan BART (Bar At The Rooftop) sangat ramai dan berlebihan, serta terdapat banyak event yang ada di ROCA dan BART, hal inilah yang menyababkan karyaw an kewalahan saat melayani tamu dan menyebabkan beban kerja yang cukup berat. Standar Operasional (SOP) di Artotel Sanur Bali pada umumnya, 1 orang pramusaji melayani 2 squere table yang terdiri dari 8 seat, jadi 1 squere table terdiri dari 4 seat dan biasanya setiap hotel menggunakan peraturan yang berbeda-beda mengenai incharge pramusaji di hotel.

Pada Tabel 8 dijelaskan bahw a ROCA (Restaurant Of Contemporary Art). Pada tahun 2016 memiliki kapasitas sebanyak 180 seat atau 45 table dan rata-rata kunjungan mencapai lebih dari 180 tamu. Berikut aturan terkait dengan daily staff incharge pada tahun 2016, karyaw an pada shift pagi dan sore incharge berjumlah 17 pagi dan 16 sore karyawan. Hal ini dikarenakan setiap harinya terdapat 8 karyawan yang sedang dalam masa libur kerja mingguan atau sedang off dan jumlah karyaw an sebanyak 41 karyawan. Kapasitas seat sebanyak 180, 1 karyawan melayani 10 seat pagi dan 11 seat sore. Hal ini tidak sesuai dengan SOP hotel yang memberlakukan 1 karyaw an melayani 8 seat serta perusahaan memberikan tugas berlebihan kepada karyaw an, banyaknya complaint yang terjadi, hubungan karyawan dengan karyawan lainnya kurang harmonis, peralatan kerja yang digunakan sering mengalami kerusakan, lamanya waktu kerja atau overtime 2 sampai 3 jam dan tidak diberikan uang lembur, jadi inilah yang menyebabkan karyawan mengalami beban kerja yang berlebihan. 
Karyaw an incharge di BART (Bar At The Rooftop) pada shift pagi dan sore berjumlah 4 pagi dan 3 sore karyawan. Hal ini dikarenakan setiap harinya terdapat 8 karyaw an yang sedang dalam masa libur kerja mingguan atau sedang off dan jumlah karyaw an sebanyak 15 karyawan. Kapasitas seat sebanyak 80, 1 karyaw an melayani 20 seat pagi dan 26 seat sore. Hal ini tidak sesuai dengan SOP hotel yang memberlakukan 1 karyawan melayani 8 seat serta perusahaan memberikan tugas berlebihan kepada karyawan, banyaknya complaint yang terjadi, hubungan karyawan dengan karyaw an lainnya kurang harmonis, peralatan kerja yang digunakan sering mengalami kerusakan, lamanya waktu kerja atau overtime 2 sampai 3 jam dan tidak diberikan uang lembur, jadi inilah yang menyebabkan karyaw an mengalami beban kerja yang berlebihan.

Pada tahun 2017, karyawan pada shift pagi dan sore di ROCA (Restaurant of Contemporary $A r t$ ) berjumlah 14 pagi dan 13 sore karyaw an. Hal ini dikarenakan setiap harinya terdapat 8 karyawan yang sedang dalam masa libur kerja mingguan atau sedang off dan jumlah karyawan sebanyak 35 karyaw an. Kapasitas seat sebanyak 180, setiap 1 karyaw ann melayani 13 seat pagi dan 14 seat sore bertambah dari tahun sebelumnya disebabkan adanya karyawan yang resign. Hal ini tidak sesuai dengan SOP hotel yang memberlakukan 1 karyawan melayani 8 seat serta perusahaan memberikan tugas berlebihan kepada karyaw an, banyaknya complaint yang terjadi, hubungan karyaw an dengan karyaw an lainnya kurang harmonis, peralatan kerja yang digunakan sering mengalami kerusakan, lamanya waktu kerja atau overtime 2 sampai 3 jam dan tidak diberikan uang lembur, jadi inilah yang menyebabkan karyaw an mengalami beban kerja yang berlebihan.

Karyaw an incharge di BART (Bar at The Rooftop) pada shift pagi dan sore berjumlah 4 pagi dan 3 sore karyawan. Hal ini dikarenakan setiap harinya terdapat 8 karyaw an yang sedang dalam masa libur kerja mingguan atau sedang off dan jumlah karyaw an sebanyak 15 karyawan. Kapasitas seat sebanyak 80, 1 karyawan melayani 20 seat pagi dan 26 seat sore. Hal ini tidak sesuai dengan SOP hotel yang memberlakukan 1 karyaw an melayani 8 seat serta perusahaan memberikan tugas berlebihan kepada karyawan, banyaknya complaint yang terjadi, hubungan karyawan dengan karyaw an lainnya kurang harmonis, peralatan kerja yang digunakan sering mengalami kerusakan, lamanya waktu kerja atau overtime 2 sampai 3 jam dan tidak diberikan uang lembur, jadi inilah yang menyebabkan karyaw an mengalami beban kerja yang berlebihan.

Pada tahun 2018, karyawan pada shift pagi dan sore di ROCA (Restaurant of Contemporary Art) berjumlah 9 pagi dan 8 sore karyaw an. Hal ini dikarenakan setiap harinya terdapat 8 karyaw an yang sedang dalam masa libur kerja mingguan atau sedang off dan jumlah karyawan sebanyak 25 karyaw an. Kapasitas seat sebanyak 180, setiap 1 karyaw an melayani 20 seat pagi dan 22 seat sore bertambah dari tahun-tahun sebelumnya disebabkan adanya karyaw an yang resign. Hal ini tidak sesuai dengan SOP hotel yang memberlakukan 1 karyawan melayani 8 seat serta perusahaan memberikan tugas berlebihan kepada karyawan, banyaknya complaint yang terjadi, hubungan karyawan dengan karyawan lainnya kurang harmonis, peralatan kerja yang digunakan sering mengalami kerusakan, lamanya waktu kerja atau overtime 2 sampai 3 jam dan tidak diberikan uang lembur, jadi inilah yang menyebabkan karyawan mengalami beban kerja yang berlebihan dan karyaw an kew alahan saat melayani tamu serta overtime.

Karyaw an incharge di BART (Bar at The Rooftop) pada shift pagi dan sore berjumlah 4 pagi dan 3 sore karyawan. Hal ini dikarenakan setiap harinya terdapat 8 karyawan yang sedang dalam masa libur kerja mingguan atau sedang off dan jumlah karyaw an sebanyak 15 karyawan. Kapasitas seat sebanyak 80, 1 karyawan melayani 20 seat pagi dan 26 seat sore. Hal ini tidak sesuai dengan SOP hotel yang memberlakukan 1 karyawan melayani 8 seat serta perusahaan memberikan tugas berlebihan kepada karyawan, banyaknya complaint yang terjadi, hubungan karyawan dengan karyaw an lainnya kurang harmonis, peralatan kerja yang digunakan sering mengalami kerusakan, lamanya waktu kerja atau overtime 2 sampai 3 jam dan tidak diberikan uang lembur, jadi inilah yang menyebabkan karyaw an mengalami beban kerja yang berlebihan.

Rata-rata setiap hari karyaw an yang bekerja mengalami overtime yang begitu lama yaitu 2 jam hingga sampai 3 jam serta perusahaan memberikan tugas berlebihan kepada karyawan, banyaknya complaint yang terjadi, hubungan karyaw an dengan karyaw an lainnya kurang harmonis, 
peralatan kerja yang digunakan sering mengalami kerusakan dan juga rata-rata karyawan yang bekerja hingga overtime tersebut, tidak diberikan gaji lebih atau uang tambahan, beban kerja inilah penyebab karyawan sering mengeluh dan hingga ada karyawan yang mengajukan resign.

Berdasarkan penjelasan diatas dapat dilihat bahwa daily staff incharge di ROCA (Restaurant of Contemporary Art) dan BART (Bar at The Rooftop) memiliki beban kerja yang mengharuskan karyaw an di food and beverage service department bekerja dengan sangat cepat dalam melayani tamu. Terbatasnya jumlah karyawan membuat kewalahan dalam melayani tamu, hal ini menjadi salah satu alasan sering terjadinya turnover yang begitu cepat, setelah melakukan wawancara terhadap beberapa karyawan, banyak dari karyaw an menjelaskan bahwa beban kerja yang berat, peralatan yang kurang, seringnya overtime, dan karyawan yang kurang sehingga ada beberapa karyawan yang tiba-tiba mengajukan resign. Dengan demikian untuk sementara waktu ini daily worker sangat dibutuhkan di departemen food and beverage service. Kinerja para karyawan tergantung dari kesiapan mereka dalam melayani tamu, kinerja merupakan prestasi kerja yang telah dic apai oleh karyawan sesuai dengan ketentuan dan standar yang telah ditetapkan oleh perusahaan. Berikut adalah jumlah guest complaint pada Tabel 9.

Tabel 9. Jumlah Guest Complaint pada Restoran di Artotel Sanur Bali Tahun 2016-2018

\begin{tabular}{|c|c|c|c|c|c|c|c|}
\hline \multirow[t]{2}{*}{ No } & \multirow[t]{2}{*}{ Tahun } & \multicolumn{4}{|c|}{ Jenis Guest Complaint } & \multirow[t]{2}{*}{ Total } & \multirow{2}{*}{$\begin{array}{c}\text { Pertumbuhan } \\
(\%)\end{array}$} \\
\hline & & Harga & Rasa & Pelayanan & Suasana & & \\
\hline 1. & 2016 & 15 & 23 & 28 & 12 & 78 & - \\
\hline 2. & 2017 & 17 & 29 & 30 & 27 & 103 & 32,05 \\
\hline 3. & 2018 & 29 & $\begin{array}{c}31 \\
\text { Total }\end{array}$ & 47 & 25 & $\begin{array}{l}132 \\
313\end{array}$ & $\begin{array}{l}28,15 \\
60,20\end{array}$ \\
\hline
\end{tabular}

Sumber: Food and Beverage Office Artotel Sanur Bali, 2019

Berdasarkan Tabel 9 di atas dapat disimpulkan bahwa pertumbuhan yang terjadi setiap tahunnya mengalami kenaikan. Jumlah pertumbuhan guest complaint tertinggi terjadi pada tahun 2017 yaitu sebesar 32,05 persen dikarenakan karena adanya karyaw an di food and beverage service department yang resign sebanyak 6 karyawan, hal ini membuat timbulnya beban kerja yang menyebabkan karyaw an kewalahan saat bekerja atau melayani tamu.

Sedangkan kenaikan jumlah guest complaint terjadi pada tahun 2018 dengan hasil pertumbuhan yaitu 28,15 persen, hal ini disebabkan karena karyawan di food and beverage service department yang resign sebanyak 10 karyawan dan adanya sistem pertukaran karyawan antara Artotel Sanur Bali dan Artotel Beach Club, hal ini membuat kurangnya karyawan, menyebabkan beban kerja terhadap karyaw an lainnya dan ketidakfokusan karyaw an dalam pelayanan sehingga membuat karyaw an merasa bingung dan belum terbiasa dikarenakan pertukaran karyawan tersebut. bahwa:

Menurut Bapak Adi selaku manager food and beverage service department menyatakan

"Keluhan para tamu yang diterima sangat diperlukan untuk diperbaiki oleh pihak restoran dan kinerja karyawan pada food and beverage service department masih sangat kurang. Terdapat berbagai jenis complaint yang disampaikan oleh para tamu yang mengunjungi restoran di Artotel Sanur Bali mulai dari harga, rasa, pelayanan dan suasana.

Guest complaint pelayanan miliki pertumbuhan tertinggi setiap tahunnya, dari tahun 2016 sampai tahun 2018, hal ini dikarenakan terbatasnya jumlah karyawan yang melayani tamu, dikarenakan ada karyawan resign setiap tahunnya dan tingginya beban kerja yang membuat karyaw an kewalahan dalam melayani tamu, hal inilah penyebab menjadi salah satu alasan tingginya guest complaint pelayanan setiap tahunnya".

\section{METODE PENELITIAN}

Penelitian ini dilakukan di Artotel Sanur Bali. Hotel ini berlokasi di Jl. Kusumasari No. 1, Sanur, Denpasar Selatan. Terdapat 2 variabel yang digunakan dalam penelitian ini. Variabel pertama yang digunakan adalah beban kerja, dengan enam indikator yaitu beban kerja yang sulit dan berlebihan, tekanan atau desakan waktu, alat bantu kerja dan sarana kerja yang kurang memadai, 
kondisi atau medan kerjayang kurang baik, hubungan pekerja dengan pekerja lainnya kurang harmonis, lamanya waktu kerja dan overtime. Variabel kedua yaitu kinerja dengan empat indikator yaitu kualitas, kuantitas pelaksanaan tugas, tanggung jawab.

Jenis data Data kuantitatif, adalah data dalam bentuk angka-angka yang dapat dihitung serta diukur jumlahnya untuk kemudian diolah dengan metode statistik. Dalam penelitian ini yang termasuk data kuantitatif berupa studi kepustakaan terkait jumlah data karyawan resign pada food and beverage service department, jumlah sampel penelitian, jumlah karyaw an yang incharge serta hasil dari kuesioner yang diukur berdasarkan satuan skala likert. Data kualitatif, adalah data yang berbentuk kata, penjelasan, skema, dan gambar.

Data kualitatif dalam penelitian ini didapat melalui pengamatan, wawancara, atau penelaahan dokumen. Jenis data kualitatif dalam penelitian ini berupa sejarah hotel, gambaran umum hotel, fasilitas yang dimiliki, struktur organisasi dan hasil w aw ancara informan terkait kinerja Artotel Sanur Bali.

Sumber data Data Primer, adalah data yang diperoleh langsung dari sumber data pertama melalui prosedur dan teknik pengambilan data yang dapat berupa waw ancara, observasi, maupun penggunaan instrumen pengukuran yang khusus dirancang sesuai dengan tujuan. Data primer dalam penelitian ini adalah hasil observasi serta jawaban dari narasumber dan responden dalam penelitian ini.

Data Sekunder, adalah data-data yang diperoleh secara tidak langsung dari responden, seperti literatur-literatur yang berhubungan dengan penelitian. Data sekunder merupakan data yang sudah tersedia sehingga kita tinggal mencari dan mengumpulkan. Data sekunder penelitian ini diperoleh dari buku, literatur, dokumen, serta arsip yang berisi data struktur organisasi, gambaran umum dan jumlah karyaw an hotel.

Teknik pengumpulan data dilakukan dengan observasi, kuesioner, wawancara, dan dokumentasi. Teknik penentuan sampel menggunakan teknik non probability sampling dilakukan dengan metode sensus, pengumpulan data dilakukan dengan penyebaran kuesioner terhadap 40 responden yang merupakan karyaw an tetap dan kontrak food and beverage service department di Artotel Sanur Bali. Teknik Analisis data dilakukan dengan pengukuran Skala Likert dan dianalisis menggunakan analisis statistik inferensial menggunakan Statitical Pacage of Social Science (SPSS).

Teknik penentuan informan Informan adalah orang yang berada pada lingkungan penelitian, artinya orang yang dapat memberikan informasi tentang situasi dan kondisi latar penelitian. Dalam penelitian ini teknik penentuan informan menggunakan purposive sampling, informan harus banyak mengetahui tentang data-data dalam penelitian ini dan secara sukarela menjadi anggota tim meskipun tidak secara formal, mereka dapat memberikan pandangannya tentang nilai-nilai, sikap, bangunan, proses, dan kebudayaan yang menjadi latar penelitian setempat. Kemudian penentuan sampel atau informan dalam penelitian adalah berfungsi untuk mendapatkan informasi yang maksimum. (Sugiyono, 2016). Informan dalam penelitian ini terdiri dari informan pangkal dan informan kunci.

Informan pangkal dalam penelitian ini informan yang mempunyai penegtahuan dan informasi yang lain, mempunyai wewenang terhadap kebenaran data, mampu memberi akses terhadap informasi lain yang lebih mendalam terhadap objek yang diteliti. Informan tersebut adalah Ibu Maya dan Pak Adi selaku human resources department dan food and beverage service department di hotel Artotel Sanur Bali.

Informan kunci dalam penelitian ini adalah orang yang dapat menjaring informasi mengenai pengalaman serta mengetahui dan paham seluk beluk tentang restoran dan bar Artotel Sanur Bali, Informan tersebut adalah Erik dan Rini yang sudah bekerja dari Artotel ini di buka sebagai karyaw an food and beverage service department di hotel Artotel Sanur Bali.

Teknik penentuan sampel Menurut Sugiyono (2016:80-81) Populasi adalah wilayah generalisasi yang terdiri atas objek yang mempunyai kualitas dan karakteristik tertentu yang ditetapkan oleh peneliti untuk dipelajari dan kemudian ditarik kesimpulan sedangkan sampel adalah bagian dari jumlah dan karakteristik yang dimiliki oleh populasi. Populasi yang memiliki karakteristik yang sama dengan populasi. Sampel adalah bagian dari jumlah dan karakteristik yang dimiliki oleh populasi tersebut.

Teknik pengambilan sampel yang digunakan dalam penelitian ini adalah Teknik Nonprobability Sampling dengan jenis sampling jenuh istilah lainnya sensus, dimana semua anggota 
populasi dijadikan sampel. Adapun yang akan menjadi populasi dalam penelitian ini adalah Karyaw an food and beverage service department Artotel Sanur Bali, diantaranya karyaw an tetapdan karyaw an kontrak yang berjumlah 40 orang.

Analisis deskriptif kualitatif Penelitian ini menggunakan analisis statistik deskriptif yang di dukung oleh deskriptif kualitatif. Menurut Utama dan Mahadewi (2012:143) menjelaskan bahwa: "Deskriptif kualitatif merupakan proses mengorganisasikan dan mengurutkan data ke dalam pola, kategori, dan satuan uraian dasar sehingga dapat ditemukan tema dan dapat dirumuskan hipotesis kerja seperti disarankan oleh data. Data yang terkumpul dengan pengamatan langsung di Artotel Sanur Bali yang berupa gambaran umum lokasi dan pembahasan hasil penelitian”.

Analisis deskriptif kuantitatif Analisis kuantitatif adalah analisis yang menggunakan rumusrumus dan angka dalam menganalisis masalah yang ditemukan dalam penelitian.

Statistik deskriptif pada penelitian ini menggunakan analisis statistik deskriptif yang didukung oleh deskriptif kuantitatif. Menurut Sugiyono (2014:7) Data Kuantitatif diartikan sebagai metode penelitian yang berlandaskan pada filsafat positivisme, digunakan untuk meneliti pada populasi atau sampel tertentu, pengumpulan data menggunakan instrumen penelitian, analisis data bersifat kuantitatif/statistik, dengan tujuan untuk menguji hipotesis yang telah di tetapkan.

Analisis Skala Likert, untuk menganalisis tanggapan atau persepsi responden digunakan pengukuran skala Likert untuk jawaban-jawaban responden sesuai dengan variabel untuk seluruh pertanyaan yang diajukan dengan pemberian skor, sebagai berikut:

1. Skor lima diberikan apabila responden memberikan tanggapan atau penilaian diharapkan sangat setuju.

2. Skor empat diberikan apabila responden memberikan tanggapan atau penilaian yang diharapkan setuju.

3. Skor tiga diberikan apabila responden memberikan tanggapan atau penilaian netral.

4. Skor dua diberikan apabila responden memberikan tanggapan atau penilaian tidak setuju

5. Skor satu diberikan apabila responden memberikan tanggapan atau penilaian sangat tidak setuju.

\section{HASIL DAN PEMBAHASAN}

Artotel Sanur Bali merupakan properti ketiga milik Artotel Indonesia, manajemen operator hotel untuk hotel desain yang terinspirasi dari seni kontemporer. Artotel Sanur Bali resmi dibuka untuk umum pada bulan april tahun 2016. Artotel Sanur Bali memiliki 89 kamar yang luas berukuran $30 \mathrm{sqm}, 40 \mathrm{sqm}$, dan $55 \mathrm{sqm}$, dengan fasilitas yang mewah dan artistik di setiap kamarnya, dilengkapi dengan balkoni, TV layar datar 49 inci, Safe Deposit Box, mesin pembuat kopi Dolce Gusto, dan koneksi internet Wi-Fi. Artotel Sanur Bali juga memiliki fasilitas resepsionis 24 jam, restoran \& bar ROCA yang menyajikan pilihan makanan Indonesia dan Barat, ruang pertemuan atau Meet Space dengan kapasitas hingga 100 orang, kolam renang yang berada di lantai paling atas atau infinity pool dan BART (bar at The rooftop), serta ArtSpace yang berfungsi sebagai galeri seni khas Artotel.

\section{Analisis Pengujian Instrumen}

Uji validitas digunakan untuk mengetahui valid atau tidaknya suatu kuesioner. Suatu kuesioner dikatakan valid jika pertanyaan pada kuesioner mampu mengungkapkan suatu yang akan diukur oleh kuesioner tersebut Ghozali (2014). Dalam penelitian ini terdapat 20 sub indikator yang diteliti valid karena nilai korelasi melebihi 0,3 $(\mathrm{df}=\mathrm{n}-\mathrm{k}$, dengan Sig 5\%). Adapun hasil dari uji validitas dapat dilihat pada Tabel 10 berikut:

Tabel 10. Uji Validitas Instrumen Penelitian

\begin{tabular}{|c|c|c|c|c|}
\hline \multirow{2}{*}{ Variabel } & Indikator & $\begin{array}{c}\text { Koefisien } \\
\text { Korelasi }\end{array}$ & $\begin{array}{c}\text { Korelasi } \\
\text { Batas }\end{array}$ & Keterangan \\
\hline \multirow{4}{*}{$\begin{array}{c}\text { Beban Kerja } \\
(\mathrm{X})\end{array}$} & $\mathrm{X} .1$ & 0,491 & 0,361 & Valid \\
\cline { 2 - 5 } & $\mathrm{X} .2$ & 0,861 & 0,361 & Valid \\
\cline { 2 - 5 } & $\mathrm{X}_{.3}$ & 0,707 & 0,361 & Valid \\
\cline { 2 - 5 } & $\mathrm{X}_{.4}$ & 0,819 & 0,361 & Valid \\
\cline { 2 - 5 } & $\mathrm{X} .5$ & 0,935 & 0,361 & Valid \\
\hline
\end{tabular}




\begin{tabular}{|c|c|c|c|c|}
\hline & X.6 & 0,940 & 0,361 & Valid \\
\hline & X.7 & 0,886 & 0,361 & Valid \\
\hline & $\mathrm{X} .8$ & 0,907 & 0,361 & Valid \\
\hline & X.9 & 0,928 & 0,361 & Valid \\
\hline & $\mathrm{X} .10$ & 0,945 & 0,361 & Valid \\
\hline & $X .11$ & 0,663 & 0,361 & Valid \\
\hline & $\mathrm{X} .12$ & 0,799 & 0,361 & Valid \\
\hline \multirow{8}{*}{$\begin{array}{l}\text { Kinerja } \\
\text { (Y) }\end{array}$} & $Y_{.1}$ & 0,848 & 0,361 & Valid \\
\hline & $\mathrm{Y}_{.2}$ & 0,830 & 0,361 & Valid \\
\hline & $\mathrm{Y}_{.3}$ & 0,862 & 0,361 & Valid \\
\hline & $\mathrm{Y}_{.4}$ & 0,848 & 0,361 & Valid \\
\hline & $Y_{.5}$ & 0,862 & 0,361 & Valid \\
\hline & Y.6 & 0,633 & 0,361 & Valid \\
\hline & Y.7 & 0,864 & 0,361 & Valid \\
\hline & $\mathrm{Y}_{.8}$ & 0,864 & 0,361 & Valid \\
\hline
\end{tabular}

Sumber: Hasil penelitian (2019).

Selanjutnya pengujian reliabilitas yang digunakan untuk melakukan pengujian terhadap hasil dari jawaban kuesioner yang telah dilakukan, fungsi dari uji reliabilitas ini dilakukan untuk memperoleh hasil penelitian yang reliabel. Adapun hasil uji reliabilitas pada penelitian ini dapat dilihat pada Tabel 11 berikut:

Tabel 11. Uji Reliabilitas Instrumen Penelitian

\begin{tabular}{|l|l|l|}
\hline \multicolumn{1}{|c|}{ Cronbach's Alpha } & \multicolumn{1}{c|}{$\begin{array}{c}\text { Cronbach's Alpha Based on } \\
\text { Standardized Items }\end{array}$} & N of Items \\
\hline .972 & .975 & 20 \\
\hline
\end{tabular}

Sumber: Hasil Pengolahan Data, 2019

Berdasarkan Tabel 11, menunjukkan bahwa seluruh instrumen penelitian memiliki koefisien Cronbach's Alpha lebih dari 0,60. Jadi dapat dinyatakan bahwa seluruh variabel telah memenuhi syarat reliabilitas atau kehandalan sehingga dapat digunakan untuk melakukan penelitian.

\section{Desk ripsi Variabel Beban Kerja Karyawan Food and Beverage Service Artotel Sanur Bali}

Beban kerja pada penelitian ini merupakan variabel bebas yang diukur dengan 12 pernyataan yang ditanggapi oleh 40 responden menggunakan 5 poin skala likert. Adapun hasil tanggapan responden dapat dilihat pada Tabel 12 sebagai berikut:

Tabel 12 Hasil Deskripsi VariabelBeban Kerja Karyawan Food and Beverage Service Artotel Sanur Bali

\begin{tabular}{|c|c|c|c|c|c|c|c|c|}
\hline \multirow[t]{2}{*}{ no } & \multirow[t]{2}{*}{ Pernyataan } & \multicolumn{5}{|c|}{$\begin{array}{l}\text { Frekuensi Jawaban } \\
\text { Responden (Orang) }\end{array}$} & \multirow[t]{2}{*}{$\begin{array}{l}\text { Rata- } \\
\text { Rata }\end{array}$} & \multirow[t]{2}{*}{$\begin{array}{l}\text { Kriteri } \\
\text { a }\end{array}$} \\
\hline & & TS & $\mathbf{S}$ & $\mathbf{N}$ & $\mathbf{S}$ & $\mathbf{S}$ & & \\
\hline \multicolumn{9}{|c|}{ Beban Kerja Yang Sulit dan Berlebihan } \\
\hline 1 & $\begin{array}{l}\text { Perus ahaan memberikan tugas yang } \\
\text { berlebihan atau beban kerja yang } \\
\text { berlebihan kepadaanda }\end{array}$ & 0 & 0 & 1 & 32 & 7 & 4,15 & Setuju \\
\hline 2 & $\begin{array}{l}\text { Lingkungan kerja anda memberikan } \\
\text { tuntutan tugas melebihi kemampuan anda }\end{array}$ & 0 & 0 & 0 & 8 & 32 & 4,80 & $\begin{array}{l}\text { Sangat } \\
\text { Setuju }\end{array}$ \\
\hline
\end{tabular}




\begin{tabular}{|c|c|c|c|c|c|c|c|c|}
\hline \multicolumn{9}{|c|}{ Tekanan atau Desakan Waktu } \\
\hline 3 & $\begin{array}{l}\text { Tekanan yang diberikan oleh atasan } \\
\text { membuat and a terbebani }\end{array}$ & 1 & 0 & 1 & 23 & 15 & 4,27 & $\begin{array}{l}\text { Sangat } \\
\text { Setuju }\end{array}$ \\
\hline 4 & $\begin{array}{l}\text { Tugas anda yang diberikan harus slesai } \\
\text { dengan rentan waktu yang sangat padat }\end{array}$ & 1 & 0 & 4 & 1 & 4 & 4,17 & Setuju \\
\hline \multicolumn{9}{|c|}{ Alat Bantu Kerja dan Sarana Kerja Kurang Memadai } \\
\hline 5 & $\begin{array}{l}\text { Kurangnya peralatan yang diperlukan } \\
\text { dalam melaks anakan suatu tugas yang } \\
\text { berdampak padakualitas produksi anda }\end{array}$ & 1 & 6 & 14 & 17 & 2 & 3,32 & Setuju \\
\hline 6 & $\begin{array}{l}\text { Peralatan kerja yang digunakan s ering } \\
\text { mengalami kerus akan sehingga } \\
\text { menyebabkan peru sahaan harus } \\
\text { memperbaiki bahkan mengganti agar anda } \\
\text { mudah dalambekerja }\end{array}$ & 1 & 6 & 13 & 18 & 2 & 3,35 & Setuju \\
\hline \multicolumn{9}{|c|}{ Kondisi Pekerjaan atau Medan Kerja yang Kurang Baik } \\
\hline 7 & $\begin{array}{l}\text { Kondisi pekerjaan anda yang kurang baik } \\
\text { dapat menimbulkan beban kerja dan } \\
\text { pekerjaan akan meras a tidak nyaman }\end{array}$ & 0 & 1 & 6 & 30 & 3 & 3,87 & Setuju \\
\hline 8 & $\begin{array}{l}\text { Situasi kerja yang dialami anda berdampak } \\
\text { kepada penurunan s emangat kerja anda, } \\
\text { karena kondisi atau medan kerja yang } \\
\text { kurang baik }\end{array}$ & 0 & 2 & 12 & 24 & 2 & 3,65 & Setuju \\
\hline \multicolumn{9}{|c|}{ Hubungan Pekerja dengan Pekerja Lainny a Kurang Harmonis } \\
\hline 9 & $\begin{array}{l}\text { Tekanan yang diciptakan oleh individu } \\
\text { maupun kelompok karena kurangnya } \\
\text { dukungan sosialdari rekan-rekan anda }\end{array}$ & 0 & 4 & 8 & 25 & 3 & 3,67 & Setuju \\
\hline 10 & $\begin{array}{l}\text { Hubungan pribadi andaden gan kelompok } \\
\text { yang buruk dan kurang harmonis }\end{array}$ & 0 & 6 & 8 & 24 & 2 & 3,55 & Setuju \\
\hline \multicolumn{9}{|c|}{ Lamanya Waktu Kerja dan Overtime } \\
\hline 11 & $\begin{array}{l}\text { Kondisi yang terjadibila } \\
\text { lingkungan kerja memberikan anda tugas } \\
\text { berlebihan hingga menyebabkan beban } \\
\text { kerja }\end{array}$ & 0 & 0 & 0 & 3 & 37 & 4,92 & $\begin{array}{l}\text { Sangat } \\
\text { Setuju }\end{array}$ \\
\hline 12 & $\begin{array}{l}\text { Waktu bekerja anda melebihi } \\
\text { batas waktu normal hingga } 2 \text { jam }\end{array}$ & 0 & 0 & 15 & 22 & 3 & 3,70 & Setuju \\
\hline \multicolumn{7}{|c|}{ Rata-rata keseluruhan variabel Beban Kerja } & 3,95 & Setuju \\
\hline
\end{tabular}

Sumber: Hasil Pengolahan Data, 2019.

Berdasarkan Tabel 12. diatas, dapat diketahui bahwa beban kerja secara keseluruhan berpengaruh terhadap kinerja. Dapat dilihat dari keseluruhan rata-rata nilai beban kerja yaitu 3,95. Nilai rata-rata tertinggi pada pernyataan "Kondisi yang terjadi bila lingkungan kerja memberikan anda tugas berlebihan hingga menyebabkan beban kerja" sebanyak 4,92. Hal ini menunjukan bahwa karyaw an food and beverage service department mengalami beban kerja dikarenakan lingkungan kerja memeberikan tugas berlebih. Berdasarkan hasil waw ancara kepada salah satu karyaw an food and beverage service department mengungkapkan bahwa:

"Terdapat banyak event yang ada di ROCA dan BART, hal inilah yang menyebabkan karyaw an kewalahan saat melayani tamu dan menyebabkan beban kerja yang cukup berat. Dalam 
setiap event yang berlangsung, salah satu contohnya event Lidah Lokal pada setiap hari senin sampai kamis dan event Cocktail Canival karyaw an diharuskan untuk menawarkan event tersebut kepada wisataw an yang sedang menginap atau wisataw an di sekitar hotel. Manajemen hotel memberikan tugas tambahan untuk mencari tamu di sekitar jalan, menyebarkan flyer, dan lain sebagainya. Kondisi tersebut menjadi beban tersendiri bagi karyaw an karena diharuskan mencari tamu agar event berjalan ramai dan banyak pengunjung".

Nilai rata-rata terendah terdapat pada pernyataan "Kurangnya peralatan yang diperlukan dalam melaksanakan suatu tugas yang berdampak pada kualitas produksi anda". Hal ini menunjukan bahwa peralatan kerja yang diperlukan tidaklah kurang dan bukan menjadi salah satu beban kerja yang mempengaruhi kualitas kerja dan kinerja karyawan.

\section{Desk ripsi Variabel Kinerja Karyawan Food and Beverage Service Department Artotel Sanur Bali}

Tabel 13 Hasil Deskripsi Variabel Kinerja Kary awan Food and Beverage Service Department di Artotel Sanur Bali

\begin{tabular}{|c|c|c|c|c|c|c|c|c|}
\hline \multirow[t]{2}{*}{ No } & \multirow{2}{*}{ Pernyataan } & \multicolumn{5}{|c|}{$\begin{array}{l}\text { Frekuensi Jawaban } \\
\text { Responden (Orang) } \\
\end{array}$} & \multirow[t]{2}{*}{$\begin{array}{l}\text { Rata- } \\
\text { Rata }\end{array}$} & \multirow[t]{2}{*}{ Kriteria } \\
\hline & & STS & TS & $\mathbf{N}$ & $\mathbf{S}$ & SS & & \\
\hline \multicolumn{9}{|c|}{ Kualitas } \\
\hline 1 & $\begin{array}{l}\text { Anda trampil dalambekerja dan } \\
\text { mempunyai inisiatif untuk membantu } \\
\text { rekan kerja }\end{array}$ & 0 & 0 & 0 & 13 & 27 & 4,67 & $\begin{array}{l}\text { Sangat } \\
\text { Setuju }\end{array}$ \\
\hline 2 & $\begin{array}{l}\text { Anda memiliki kemampuan untuk } \\
\text { bekerja dengan telitidan tetap sesuai } \\
\text { standar kualitas kerja yang dityentukan }\end{array}$ & 0 & 0 & 0 & 30 & 4 & 3,95 & Setuju \\
\hline \multicolumn{9}{|c|}{ Kuantitas } \\
\hline 3 & $\begin{array}{l}\text { Kuantitas kerja anda sudah sesuai } \\
\text { dengan standar kerja yang diharapkan } \\
\text { oleh peru sahaan }\end{array}$ & 0 & 0 & 11 & 25 & 4 & 3,82 & Setuju \\
\hline 4 & $\begin{array}{l}\text { Pekerjaan yang dihasilkan oleh anda } \\
\text { sesuai dengan target yang telah } \\
\text { ditetapkan perusahaan }\end{array}$ & 0 & 0 & 13 & 23 & 4 & 3,77 & Setuju \\
\hline \multicolumn{9}{|c|}{ PelaksanaanTugas } \\
\hline 5 & $\begin{array}{l}\text { Anda mampu melakukan pekerjaan } \\
\text { dengan akurat atau tidak ada kes alahan }\end{array}$ & 0 & 0 & 11 & 24 & 5 & 3,85 & Setuju \\
\hline 6 & $\begin{array}{l}\text { Anda mampu melaksanakan tugas } \\
\text { dengan baik }\end{array}$ & 0 & 0 & 0 & 21 & 19 & 4,47 & $\begin{array}{l}\text { Sangat } \\
\text { Setuju }\end{array}$ \\
\hline \multicolumn{9}{|c|}{ Tanggung Jawab } \\
\hline 7 & $\begin{array}{l}\text { Anda bertang gung jawab atas pekerjaan } \\
\text { dilakukan }\end{array}$ & 0 & 0 & 0 & 7 & 33 & 4,83 & $\begin{array}{l}\text { Sangat } \\
\text { Setuju }\end{array}$ \\
\hline 8 & $\begin{array}{l}\text { Anda menerima resiko daritindakan } \\
\text { yang dilakukan }\end{array}$ & 0 & 0 & 0 & 7 & 33 & 4,82 & $\begin{array}{l}\text { Sangat } \\
\text { Setuju }\end{array}$ \\
\hline \multicolumn{7}{|c|}{ Rata-rata keseluruhan variabel Kinerja } & 4,27 & $\begin{array}{l}\text { Sangat } \\
\text { Setuju }\end{array}$ \\
\hline
\end{tabular}

Sumber: Hasil Pengolahan Data, 2019.

Berdasarkan Tabel 13 diatas, dapat diketahui bahwa kinerja karyaw an dipengaruhi oleh beban kerja dari keseluruhan rata-rata nilai kinerja yaitu 4,27. Nilai rata-rata tertinggi pada pernyataan "Anda bertanggung jaw ab atas pekerjaan dilakukan". Hal ini menunjukan karyawan memiliki komitmen untuk terus bertanggung jaw ab atas pekerjaan yang telah ditugaskan oleh hotel.

Selanjutnya dilakukan uji Analisis hasil regresi linier sederhana bertujuan untuk mengetahui pengaruh satu variabel bebas, Beban Kerja (X) terhadap satu variabel tak bebas Kinerja (Y) apakah positif atau negatif untuk memprediksi besaran nilai dari variabel terikat (dependent). Berikut pada 
tabel 3 akan dibahas mengenai hasil dari analisis regresi linier sederhana yang dibantu dengan program SPSS versi 17.0 for Windows.

Tabel 14. Coefficients Antara Variabel Beban Kerja dan Variabel Kinerja

\begin{tabular}{|cc|c|c|c|c|c|}
\hline \multirow{2}{*}{} & \multicolumn{3}{|c|}{ Unstandardized Coefficients } & $\begin{array}{c}\text { Standardized } \\
\text { Coefficients }\end{array}$ & & \\
\cline { 2 - 4 } & Model & $\mathrm{B}$ & Std. Error & Beta & $\mathrm{T}$ & Sig. \\
\hline 1 & (Constant) & 18.072 & 3.745 & & 4.826 & .000 \\
& $\mathrm{X}$ & .340 & .079 & .574 & 4.325 & .000 \\
\hline
\end{tabular}

a. Dependent Variable: Y

Sumber:Hasil Pengolahan Data, 2019.

Berdasarkan Tabel 13 diperoleh hasil $\mathrm{Y}=18.072,0.340 \mathrm{X}$, persamaan yang diperoleh dapat menjelaskan pola pengaruh beban kerja $(\mathrm{X})$ terhadap variabel terikat kinerja (Y) sebagai berikut:

1. Constanta $(\alpha)=\mathrm{Y}$ adalah besaran nilai variabel dependent (kinerja), yaitu sebesar 18.072.

2. Koefisien regresi $(b)=0.340$ yang mengartikan besaran nilai yang dipengaruhi oleh variabel independent (beban kerja)

3. Kesimpulannya adalah bahwa terdapat pengaruh yang positif antara beban kerja terhadap kinerja karyaw an food and beverage service department di hotel Artotel Sanur Bali. Bila X (beban kerja bertambah sebesar 1 (satu) satuan, maka nilai Y (Kinerja) akan meningkat sebesar 0.340 atau $34 \%$.

\section{Hasil Uji t}

1. Menentukan hipotesis nol (H0) dan hipotesis alternative (Ha)

a. H0: Tidak terdapat pengaruh antara Beban Kerja terhadap Kinerja Karyawan Food and Beverage Service Department Artotel Sanur Bali.

b. Ha: Terdapat pengaruh antara Beban Kerja terhadap Kinerja Karyawan Food and Beverage Service Department Artotel Sanur Bali.

2. Hipotesis bentuk statistik

a. H0: $\beta \leq 0$, berarti "tidak ada pengaruh antara beban kerja terhadap kinerja".

b. Ha: $\beta>$ berarti "ada pengaruh antara beban kerja terhadap kinerja".

3. Pengujian

Hasil analisis regresi linier sederhana disebutkan besaran terhitung $=4.325$. Nilai $t_{\text {tabel }}$ dicari dengan menggunakan tabel distribusi t. Menentukan level of significant 95 persen dengan tingkat kesalahan $(\alpha)$ dalam penelitian ini ditentukan sebesar 5 persen dan $\mathrm{df}=(\mathrm{n}-\mathrm{k}-1)$ untuk menentukan $t_{\text {tabel }}$.

df $\quad=(\mathrm{n}-\mathrm{k}-1)$

$=(40-1-1)=38$, pada LOS 5 persen didapatkan t-tabel 2.024.

4. Membandingkan $t_{\text {hitung }}$ dengan $t_{\text {tabel }}$

Berdasarkan hasil pengujian menunjukan bahwa nilai Sig, untuk pengaruh beban kerja terhadap kinerja karyawan food and beverage service department di Hotel Artotel Sanur sebesar $0,000<0,05$, dengan nilai $t_{\text {hitung }} 4.325>t_{\text {tabel }}$ (2.024), maka dapat dinyatakan bahwa H0 ditolak, artinya bahwa adanya pengaruh signifikan antara beban kerja terhadap kinerja karyaw an food and beverage service department di hotel Artotel Sanur Bali.

Daerah penerimaan dan penolakan $\mathrm{H} 0$ dapat dilihat pada Gambar 1 berikut ini: 


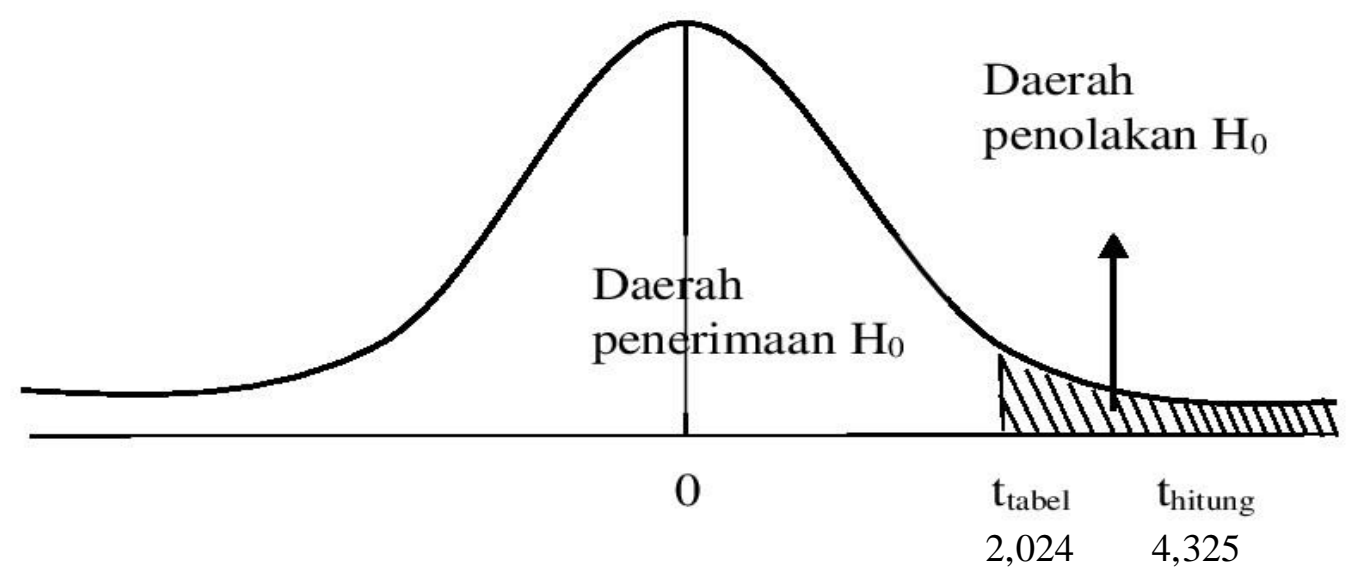

Sumber: Hasil Pengolahan Data, 2019.

Gambar 1. Daerah Penerimaan dan Penolakan H0

Berdasarkan kurva diatas, maka diperoleh $t_{\text {hitung }}$ Beban Kerja $(4,325)>t_{\text {tabel }}(2,024)$ ini berarti terdapat pengaruh yang signifikan antara beban kerja terhadap kinerja karyaw an food and beverage service department di hotel Artotel Sanur Bali.

Hasil penelitian ini selaras dengan temuan peneliti terdahulu seperti yang dilakukan oleh Nurdyani, (2016) yang melakukan penelitian di Bandung, hasil penelitiannya membuktikan bahwa beban kerja berpengaruh positif dan signifikan terhadap kinerja karyawan.

Hasil penelitian mengenai beban kerja dijelaskan oleh Irfan, (2018) yang mengungkapkan bahwa beban kerja memberikan pengaruh yang signifikan terhadap kinerja karyawan. Beban kerja yang berlebihan akan menentukan kualitas kinerja karyawan. Menurut Soleman, (2011:82) Beban kerja adalah: "Sejumlah proses atau kegiatan yang harus diselesaikan oleh seorang pekerja dalam jangka waktu tertentu. Apabila seorang pekerja mampu menyelesaikan dan menyesuaikan diri terhadap sejumlah tugas yang diberikan, maka hal tersebut tidak menjadi suatu beban kerja. Namun, jika pekerja tidak berhasil maka tugas dan kegiatan tersebut menjadi suatu beban kerja”.

Beban kerja yang berat dan berlebihan dapat memberikan tekanan bagi karyawan, ini merupakan suatu hal yang di sampaikan oleh karyawan. Oleh karena itu beban kerja yang berat dan berlebihan menjadi salah satu penyebab bagi karyawan ingin mengajukan resign.

Tabel 14. Hasil Analisis Koefisien Determinasi

\begin{tabular}{|c|c|c|c|c|}
\hline Model & $\mathrm{R}$ & R Square & Adjusted R Square & $\begin{array}{c}\text { Std. Error of the } \\
\text { Estimate }\end{array}$ \\
\hline 1 & $.574^{\mathrm{a}}$ & .330 & .312 & 2.19169 \\
\hline
\end{tabular}

a. Predictors: (Constant), $\mathrm{X}$

Sumber: Hasil Pengolahan Data, 2019

Berdasarkan Tabel 14 diatas dapat diketahui besarnya pengaruh Beban Kerja (X) terhadap Kinerja (Y) yaitu sebesar 33\%, sedangkan sisanya 67\% dipengaruhi oleh variabel lain yang tidak dibahas dalam penelitian ini. Hal ini berarti bahwa sebesar 33\% persen kinerja dipengaruhi oleh variabel beban kerja, sedangkan sisanya sebesar 67\% dipengaruhi oleh faktor lain yang tidak termasuk dalam penelitian ini seperti upah kerja, stres kerja. Beban kerja berpengaruh nyata ( $\mathrm{p}<$ $0,05)$ terhadap kinerja dengan hasil dari nilai koefisien regresi beban kerja sebesar 33\%, artinya bahwa apabila terjadi kenaikan satu nilai Beban Kerja (X) maka akan memberikan peningkatan nilai pada Kinerja (Y).

Hasil analisis menunjukan bahwa pengaruh beban kerja terhadap kinerja karyawan menunjukkan satu komprasi yang mengarah pada lebih tingginya pengaruh beban kerja terhadap kinerja karyawan. Artinya bahw a beban kerja yang berat dan berlebihan dapat mempengaruhi kinerja karyawan. Pengaruh positif dan signifikan yang ditunjukkan variabel beban kerja terhadap kinerja 
karyawan membuktikan bahwa Artotel Sanur Bali membutuhkan upaya yang baik untuk mengatasi beban kerja tersebut.

Tabel 15. Hasil Analisis Koefisien Korelasi

\begin{tabular}{|c|c|c|c|c|}
\hline Model & $\mathrm{R}$ & R Square & Adjusted R Square & $\begin{array}{c}\text { Std. Error of the } \\
\text { Estimate }\end{array}$ \\
\hline 1 & $.574^{\mathrm{a}}$ & .330 & .312 & 2.19169 \\
\hline
\end{tabular}

a. Predictors: (Constant), X

Sumber: Hasil Pengolahan Data, 2019.

Berdasarkan Tabel 15 menunjukkan bahwa besarnya koefisien korelasi yaitu $(\mathrm{R}=0.574)$, berarti variabel dependen (beban kerja) mempunyai hubungan yang sedang dengan variabel dependen (kinerja karyawan).

\section{KESIMPULAN}

Berdasarkan hasil penelitian, terdapat pengaruh yang signifikan terhadap beban kerja terhadap kinerja karyawan dari hasil pengolahan data memperoleh hasil bahwa beban kerja (x) mendapatkan nilai sig yakni 0.000 yang dimana kurang dari 0.05 . Hal tersebut sesuai dengan penerimaan hipotesis yang dimana dikatakan berpengaruh signifikan beban kerja terhadap kinerja karyawan. Adapun nilai t-hitung dari beban kerja sebagai berikut 4,325, nilai tersebut lebih besar dari nilai t-tabel yakni 2.024 hal tersebut sesuai dengan penerimaan hipotesis yakni jika t-hitung lebih besar dari t-tabel maka terdapat pengaruh variabel beban kerja $\mathrm{X}$ secara parsial terhadap variabel kinerja Y di Artotel Sanur Bali.

Berdasarkan hasil penelitian didapat kendala yang mempengaruhi beban kerja karyawan, hal ini dikarenakan berkurangnya jumlah tenaga karyaw an di department food and beverage service. Alasan tinggimnya turnover di department food and beverage service disebabkan beberapa hal diantaranya terdapat banyak masalah antara karyawan dan manjemen. Karyawan mengalami beban kerja yang sulit dan berlebihan sehingga sering terjadinya overtime melebihi dari 2 jam. Tekanan atau desakan waktu dalam bekerja, kondisi atau medan kerja yang kurang baik dan alat bantu kerja dan sarana kerja kurang memadai. Alasan tersebut membuat karyaw an merasa terbebani dan tidak nyaman, sehingga banyak karyaw an yang mengajukan resign. Upaya untuk mengatasi beban kerja terhadap kinerja karyaw an department food and beverage service adalah perusahaan lebih fokus lagi memperhatikan karyawannya, dengan cara memberikan upah lembur untuk karyaw an yang melawati batas jam kerja sampai 2 - 3 jam atau memberikan promosi jabatan kepada karyaw an yang dinilai sudah lama bekerja dan baik dalam melakukan pekerjaannya, selalu menjaga hubungan baik antara manajemen perusahaan dengan karyaw an atau hubungan karyaw an dengan karyawan lainnya dengan memberikan kegiatan refreshing atau outing untuk karyawan, sehingga mencegah terjadinya karyaw an terbebani memikirkan beban kerjanya serta hubungan sesama karyawan dan kerja sama team juga harmonis.

Saran Berdasarkan simpulan penelitian dapat disampaikan saran-saran sebagai berikut:

1. Kepada karyaw an food and beverage service department agar lebih meningkatkan kinerja dan kerjasama team walaupun terdapat beban kerja dalam pelaksaan tugas pekerjaan yang diberikan pihak Artotel Sanur Bali.

2. Kepada Management Artotel Sanur Bali agar tetap memperhatikan karyawan agar dapat meningkatkan kinerja karyawan. Dengan meningkatnya kinerja maka akan memberikan efek yang sangat bagus bagi perusahaan khususnya di dalam melayani wisatawan.

\section{Ucapan terima kasih}

Puji syukur penulis panjatkan kehadirat Ida Shang Hyang Widhi Wasa atas rahmat dan karunia-Nya, penulis dapat menyelesaikan laporan akhir yang berjudul "Pengaruh Beban Kerja Terhadap Kinerja Karyawan Pada Food And Beverage Service Department di Hotel Artotel 


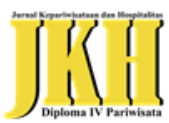

JURNAL KEPARIWISATAAN DAN HOSPITALITAS

Vol. 4, No. 1, April 2020.

Sanur Bali”. Adapun tujuan dari penulisan laporan akhir ini yaitu memenuhi persyaratan pendidikan pada Program Studi Diploma IV Pariwisata Universitas Udayana. Penyusunan laporan akhir ini dapat terwujud karena bantuan dan bimbingan dari berbagai pihak, maka melalui kesempatan ini penulis menyampaikan terima kasih yang sebesar-besarnya kepada orang tua dan keluarga, sahabat dan teman. Pihak Artotel Sanur Bali, dosen pembimbing, serta staf dan dosen Fakultas Pariwisata UNUD yang sudah membantu baik materi maupun materil.

\section{DAFTAR PUSTAKA}

Soleman, Aminah. 2011. Analisis Beban Kerja Ditinjau Dari Faktor Usia Dengan

Pendekatan Recommended Weiht Limit. Jurnal Arika, Vol.05 No.02.

Hart, S.G. dan Staveland, L.E, 1988, Development of NASA task Load Indeks (TLX): Result of Empirical and Theoritical Research, NASA-Ames Research, California.

Bungin, B. (2007). Penelitian Kualitatif. Jakarta: Prenada Media Group.

Davis, K. et al. (2000). Perilaku Dalam Organisasi. Jakarta: Erlangga

Dessler, G. (2006). Manajemen Sumber Daya Mnusia. Jakarta : PT. Indeks

Endar, S. et al. (1998). Pengantar Akomodasi Dan Restoran. Jakarta: PT. Gramedia Pustaka Utama.

Goodman, R. J. (2002). F\&B Service Manajement. Jakarta: Erlangga.

Handoko, T. H. (1998). Manajemen Personalia Dan Sumber Daya Manusia. Yogyakarta: BPFE

Handoko, T. H. (2001). Manajemen. Yogyakarta: BPFE-Yogyakarta.

Hasibuan, M. S. P. (2006). Manajemen Sumber Daya Manusia. Jakarta: Bumi Aksara.

Kountur, R. (2007). Metode Penelitian. Jakarta: PPM.

Mangkunegara, Anw ar Prabu AA. (2006). Perencanaan dan Pengembangan Sumber DayaManusia. Bandung: PT Refika Aditama.

Michael, B. (1984). Restaurant Employees. New York: Macmillan Publishing Company.

Ninemeier, J. D. (2005). Management Of Food and Beverage operations. Michigan: Education Institute Of The American Hotel And Lodging Association.

Richard, S. (2000). Food Service (Tata Hidangan). Surabaya: SIC.

Siregar. S.(2014). Statistik Parametrik Untuk Penelitian Kuantitatif. Jakarta : PT Bumi Aksara

Sugiyono. (2008). Metode Penelitian Kuantitatif, Kualitatif, dan R\&D. Bandung : Alfabeta

Stoner, J.et al. (1996). Manajemen. New Jersey: Prentice-Hall, Inc.

Sastrohadiwiryo, B. S. (2003). Manajemen Tenaga Kerja Indonesia. Jakarta: PT Bumi Aksara.

Umar. H. (2005).SDM Dalam Organisasi. Jakarta: PT Gramedia Pustaka Utama

Wardiyanta. (2014) Metode Penelitian Pariwisata. Yogyakarta : Andi

Sumber Online:

http://2013/07/stres-di-tempat-kerja.html. Diakses pada 31 November 2018.

http://tesisdisertasi.blogspot.co.id/2014/10/contoh-kuesioner-penelitian-skala-likert.html?m=0.

Diakses pada 31 November 2018.

http://travel.kompas.com/read/2015/02/04/160700527/Bali.Kelebihan.Hotel Diakses pada 16 Desember 2018.

http://www .rumahproperti123.com/berita-

roperti.html?id=Hotel_di_Bali_makin_menjamur,_picu_perang_tarif_harga Diakses

pada pada 16 Desember 2018.

http://setabasri01.blogspot.co.id/2011/01/beban-kerja-satisfaction.html. Diakses pada 16 Desember 2018.

http://ikipwates-andi.blogspot.co.id/2014/06/beban-kerja-kinerja.html. Diakses pada 16 Desember 2018. 